ARTICLE HISTORY: Received: October 04, 2021 Accepted: November 26, 2021 Published: December 03, 2021

\title{
A BRIEF STUDY OF THE FLORISTIC COMPOSITION OF ALGAE IN PURIFICATION FACILITIES AND ON THE REGULARITIES OF THEIR DEVELOPMENT
}

\author{
Mustafayeva M.I. \\ Associate professor of the Department of Medical Biology, \\ BukSMI, Candidate of Biological Sciences \\ Bukhara State Medical Institute \\ Uzbekistan, Bukhara
}

\begin{abstract}
The hydrochemical composition of pond water, which plays a major role in the development and formation of algae flora, has been clarified, as a result, it has been established that pollution of ponds with organic, mineral and toxigenic substances increases from municipal, industrial effluents. Due to this, the species composition of water changes. Ecological and sanitary assessment of biological ponds based on the species composition of algae is given. Comparative analyzes of the algoflora of biological ponds of the purification facilities of Bukhara with the analogous flora of the ponds of Uzbekistan and a detailed study of the algae flora of biological ponds of the purification facilities of Bukhara are given.

Keywords: algoflora, indicative role, saprobicity, hydrochemistry, effluents, biological pond, algae biomass, reservoir, waste water.
\end{abstract}

The algoflora of individual artificial reservoirs of Central Asia, the composition of the phytoplankton of the houses, the canals of the environs of Old Bukhara were originally described in the works of A.I. Kiselev $(1926,1930,1931)$ and indicated 600 species of algae belonging to the surveyed water bodies. EI Kiseleva $(1931,1939)$ studied the vegetation of reservoirs in the vicinity of Old Bukhara. According to Kiselev's data, the following types of algae are mainly characteristic of the water bodies of Bukhara: Pediastrum duplex, P. simplex, P. clatharatum, Tetraedron costatum var. palatinum, T. limneticum, T. lobatum, T. trigonum, Kirchneriella botryoides, Ankistrodesmus falcatus, A. longissimus, Scenedesmus opoliensis, S. quadricauda, Crucigenia emarginata, C. rectangularis, Coelastrum microsporum, C. reticultum, Selenastrum gracile, Actinastrum hantzschii, Dictyosphaerium pulchellum.

The main patterns of distribution and development of algae in various water bodies of Central Asia were studied by A.M. Muzafarov. The results of many years of research by the author were published in the monograph "The flora of algae in the reservoirs of Central Asia" (1965).

According to Muzafarov (1958), the systematic list of the flora of algae in mountain water bodies of Central Asia includes 812 species and varieties: pyrrophyta 2 , golden 4 , red 5 , charophytes 6 , euglena 11 , blue-green 158 , green 171 , diatoms 469. Of these, 269 taxa are new for Central Asia.

For natural and individual artificial reservoirs of Central Asia, the author lists 2807 taxa, of which red 8, golden 22, charophytes 31, yellow-green 35, pyrophyte 42, euglena 107, blue-green 590, green-806, diatoms 1160 (Muzafarov, 1965).

As you can see, a lot of work has been done to study the flora and vegetation of the reservoirs of Central Asia, but in many of them there is no comprehensive information about the algal flora of artificial reservoirs in Central Asia.

There is no complete information on the floristic composition of algae in the treatment facilities of Bukhara and on the patterns of their development to this day.

The hydrochemical composition of pond water, which plays a major role in the development and formation of algal flora, ecological and sanitary assessment of biological ponds based on the species composition of algae, and research results make a significant contribution to the knowledge of the algal flora of the water bodies of the Bukhara region. The data obtained can be used to compile a guide to algae in water bodies of Central Asia.

For improvement of water quality, specific biological methods of wastewater treatment from municipal and industrial enterprises are recommended.

The treatment facilities of Bukhara are located on the 2nd left-bank terrace of the Zerafshan river valley, in $2.8 \mathrm{~km}$ south of the border of the city of Bukhara and is located in 180-200 meters south of the Kagan-Ashgabat railway. B 480750 metersto the west of the sites of treatment facilities there is a collector named after Sakovich. The plot has the shape of a rectangle elongated from north to south. The relief of the site is calm with insignificant drops from north-east to southwest.

Ground elevations range from 215.1 to 213.6 meters. The total slope of the site from northeast to southwest is 0.00014. The site is a desert, highly saline difference composed of alluvial deposits of the Quaternary age from: gray loams, fine-grained water-saturated sand, sandy clay and small rounded gravel of crystalline rocks. The groundwater is highly mineralized. Salinization is sulfate-chloride. Depth of groundwater 1.20-2.20 meters. On the territory of the site there are artificial ditches, with a total length $1530 \mathrm{~m}$, with a middle section $0.7 \mathrm{~m} 2$, and also houses and structures are located. The plot area has key wire fences. The basis for the development of the general plan for the site of sewage 
treatment facilities in Bukhara is: a technological scheme for the placement of buildings and structures on the site and a high-rise scheme for water for structures associated with the technology of works on sewage treatment.

Sewerage of the city is carried out by a system of gravity collectors, the main of which are Western, Central, and Southern. Wastewater treatment is accepted as complete biological in artificially created conditions (in aeration tanks) with additional treatment in biological ponds.

Discharge of treated and disinfected wastewater is carried out into the Parallel collector through the Sakovich collector. The system is designed for a prospective flow rate of 200 thousand $\mathrm{m}^{3} /$ day.

The oasis is characterized by a sharply continental climate with high dryness in summer and relatively cold winter.

The average annual temperature throughout the territory ranges from $13.8-15.1^{\circ} \mathrm{C}$, the coldest month of the year is January, and the hottest month is July. The average January temperature throughout the oasis varies within $0.6-1.8^{0} \mathrm{C}$. The average July temperature reaches $29.1-30.1^{0} \mathrm{C}$, increasing as it approaches the desert strip. Absolute minimums, falling mainly in December, January, range from 14 to $18^{\circ} \mathrm{C}$. Summer months are characterized by high temperatures with an absolute maximum of up to $45^{\circ} \mathrm{C}$, the annual temperature range seems to be quite significant.

The fallout of atmospheric precipitation coincides with the winter-spring period, during which about $85 \%$ of the annual amount falls. They do not exceed 114-132 $\mathrm{mm}$ on average over a long-term period.

The phytoplankton of bioponds is one of the most important producers of organic matter, on the basis of which the subsequent links of organic life develop. The role of phytoplankton in general, the cycle of consumer substances, abundance, distribution in the reservoir, seasonal frequency of development and their production capabilities.

In the works of a number of authors, an analysis was carried out on the prevailing algae in the studied water bodies.

The dynamics of the development of the dominant species and their number and biomass, as well as saprobic species and their indicator role in the self-purification of water and the scientific results taken can be used in writing textbooks and books for students in the course of algology, hydrobiology, ecology and environmental protection.

\section{REFERENCES}

1. Kiselev I.A. Plankton of labor (Hauza) of the Nau city of Old Bukhara, its composition and frequency due to changes in the physicochemical conditions of the aquatic environment. Proceedings of Uzb. Institute of Tropical Medicine. T-1, issue 1, 1930, p. 118.

2. Muzaffarov A.M. Flora of algae in water bodies of Central Asia Tashkent. Fan, 1965, 162 pp.

3. M. I. Mustafaeva, Khakimova Z.Z. The study of the ecology of the algae of sewage as biotechnological disciplines. International Conference Europe science and we. 2019. pp. 978-980

4. M.I.Mustafayeva. Ecological and Sanitary Assessment of Biological ponds based on the species composition of algae.European Journal of Molecular \& Clinical Medicine. Volume 7. No. 3. pp. 3625-3635 